anterior and posterior angles making it appear constricted in the ruidde, it is channelled with an irregular discoidal impression on each side; a few large dusky punctures are observable where the chamnel terminates; elytra with ten equidistant rows of large punctures which converge at the apex; besides these there is an abbreviated row at the base next the suture, as in many Harpalidae, \&c., the apex of the elytra terminates in two teeth or spines; the inner one short and dentiform, the outer one long and spiniform; legs and anal portion of the abdomen yellow, the former with all their articulations dusky at the extremity.

'The sculpture of the elytra in this species much resembles that of another aquatic genus Haliplus, Lat.

\title{
ON SOME OF OUR COMMON INSECTS
}

5. THE GRAPE VINE PLUME.-Pterophorus periscelidactylus.

BY W. SAUNDERS, LONDON, ONTARIO.

During the latter part of this month and early June those who have grape vines under their charge are often annoyed at finding

Fig. 15.

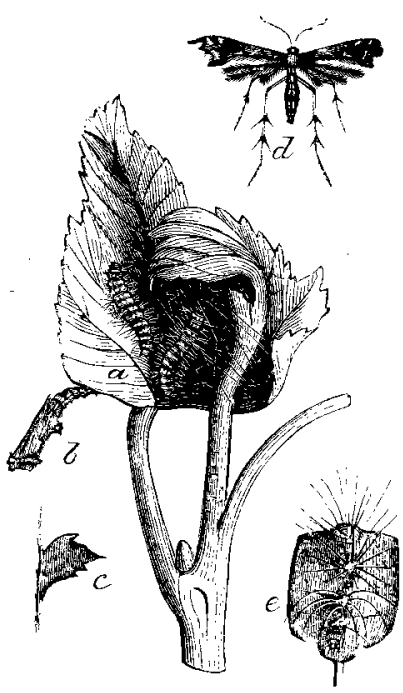

the terminal leaves of the young and tender branches tied by means of silken threads into a sort of ball shaped mass, and within the hollow sphere thus formed is found a small whitish hairy caterpillar, which feasts on the tender leaves and young blossom bunches. Usually but a single occupant is found in each enclosure, but occasionally we have found two, and, in one instance, three.

The very young larva is said to be smooth, or nearly so, the hairiness becoming more perceptible after each moult.

In fig. 15 this larva is represented nearly full grown at $a$. It is then about half an inch long with a small yellowish green head, with a band of black acros; the front, and a yellow green body, with transverse rows of dull yellow tubercles from each of which arises 
a small tuft of white hairs. There is a darker green line down the centre of the back, and the colour of the body becomes a little paler between the segments or rings. The under side is somewhat darker in colour than the upper, witl a few whitish hairs. It becomes full grown about the middle of June, and then changes to a chrysali.

The chrysalis, fig. $15, b$, is a very odd looking thing, nearly hal? an inch long; angular and rugged in outline. It wriggles and trist, abont very briskly when touched. At first it is of a pale yellowish green colour, which gradually changes to a reddish brown. We have often found them attached to the under side of the leaves.

In less than a fortnight the noth, $d$, fig. 15, makes its appearance. It is an elegant little creature; its wings are very delicately construcled and measure, when expanded, about seven-tenths of an inch. The fore wings are long and narrow and cleft down the middle about half way to their base, the posterior half of the wing having a notch in: the outer margin. They are of a yellowish brown colour and metallic iustre, with several dull whitish streaks and spots. The hind wings are divided into three lobes; the lower division is complete, extending to the base, while the upper one is only about two-thirds as deep; their colour is yellowish brown also, with the same burnished metallic appearance, and with a streak of dull white on the hinder lobe. The outer and hind margins of the wings, as well as all the edges of theit lobes, are beatufully bordered with a deep whitish fringe, sprinkled with brown. The body of the moth is long and slender, and of $a$ iittle darker colour than the wings; the legs are also long, banded alternately with yellowish brown and white, and powdered with metalli. scales. The unnatural grouping of the leaves when fastened together to form the home of this insect while in the larval state, leads to it: ready detection, when it may be easily crushed with the hand. It $i$ : very generally distributed throughout the provinces of Ontario and Quebec.

\section{ADVERTISEMENTS}

ExCHANGF.-I am desirous to exchange English for Canadian or American Lepidoptera. I. C. WASsiziman, Beverly Terrace, Cullercoats, North Shields, England.

COLFOPTI:RA FOR SALF-A number of Rocky Mountain Coleop. tera will soon be for sale in sets by JoHn Aminurst, 19, Prospect Street, Brooklyn, N. Y.

\section{TO CORRESPONDEN'TS}

J. C. Wassirmañ-Plusia balluca is very like P. chrysitis. We know the latter insect well. 